\title{
Boomjuridischtijdschriften
}

\section{De invloed van schending van de civielrechtelijke zorgplicht door de beleggingsdienstverlener op de toetsing van de overige vereisten van onrechtmatige daad en wanprestatie}

\author{
Mr. I.P.M.J. Janssen *
}

\begin{abstract}
Als een beleggingsdienstverlener zijn civielrechtelijke zorgplicht schendt, dan beïnvloedt dat feit vervolgens de toetsing van de overige vereisten van wanprestatie en onrechtmatige daad (relativiteit, causaal verband, schade en eigen schuld). In dit artikel komt aan de orde hoe die toetsing wordt beïnvloed en welke betekenis bij die toetsing aan de toezichtrechtelijke regels zou moeten toekomen.
\end{abstract}

\section{Inleiding}

Beleggen leidt niet altijd tot de resultaten die een belegger voor ogen heeft. Sommige beleggers die verliezen lijden, spreken vervolgens hun beleggingsdienstverlener aan voor deze verliezen. Zij beroepen zich dan op schending van de civielrechtelijke zorgplicht van de beleggingsdienstverlener, ook wel aangeduid als de 'bijzondere' zorgplicht. De Hoge Raad heeft namelijk bepaald dat de maatschappelijke positie van banken - en dus ook van beleggingsdienstverleners - een bijzondere zorgplicht met zich brengt tegenover zowel hun cliënten als derden. ${ }^{\mathbf{1}} \mathrm{De}$

(bank)beleggingsonderneming is namelijk bij uitstek deskundig en professioneel. De bijzondere zorgplicht strekt ertoe om de particuliere belegger te beschermen tegen het gevaar van eigen lichtvaardigheid en een gebrek aan inzicht. ${ }^{2}$ De omvang van deze verplichting is afhankelijk van de omstandigheden van het geval. ${ }^{\mathbf{3}}$ Deze benadering van de Hoge Raad duid ik hierna aan als de 'huidige benadering'.

Waar de Hoge Raad spreekt van een bijzondere zorgplicht, spreek ik hierna van de civielrechtelijke zorgplicht. ${ }^{4}$ Op deze civielrechtelijke zorgplicht zijn onder andere Europeesrechtelijke toezichtregels - meer specifiek de Markets in Financial Instruments Directive (II) (MiFID (II) $)^{5}$ - van invloed die zijn geïmplementeerd in de Wet op het financieel toezicht (Wft) en het Besluit gedragstoezicht financiële ondernemingen (Bgfo). ${ }^{6}$ Die regels bepalen hoe een 
beleggingsdienstverlener zich moet gedragen tegenover zijn cliënten. In paragraaf 3 ga ik in op de relevantie van die regels voor de civielrechtelijke zorgplicht.

Met het vaststaan van een schending van de civielrechtelijke zorgplicht is de belegger er echter nog niet. De grondslag voor het beroep op schending van de civielrechtelijke zorgplicht is de onrechtmatige daad en/of wanprestatie, ${ }^{7}$ en dus moet de belegger het causaal verband aantonen, bekijkt de rechter de omvang van de schade en bieden leerstukken als voordeelsverrekening, eigen schuld en de schadebeperkingsplicht een mogelijkheid om de te vergoeden schade te verminderen. ${ }^{\mathbf{8}}$ De relativiteit, het causaal verband, de omvang van de schade en de mogelijkheden tot schadevermindering noem ik hierna de 'overige vereisten'.

De vraag rijst in hoeverre het feit dat de beleggingsdienstverlener zijn civielrechtelijke zorgplicht heeft geschonden, doorwerkt in de toetsing van de overige vereisten. ${ }^{9}$ Hanteert de civiele rechter bij het vaststellen van eigen schuld bijvoorbeeld een ander criterium dan in het algemeen bij andere procedures omdat sprake is van schending van de civielrechtelijke zorgplicht? In paragraaf 2 bespreek ik allereerst in welke gevallen schending van de civielrechtelijke zorgplicht de toetsing van de overige vereisten in de huidige benadering beïnvloedt. In paragraaf 3 ga ik in op de positie van de Europeesrechtelijke toezichtregels bij de bepaling van de omvang van de civielrechtelijke zorgplicht. In paragraaf 4 bespreek ik vervolgens of de toepassing van het effectiviteitsbeginsel een ander licht werpt op de invloed van de schending van de civielrechtelijke zorgplicht op de toetsing van de overige vereisten. In paragraaf $5 \mathrm{kom}$ ik tot een conclusie.

\section{De invloed van schending van de civielrechtelijke zorgplicht op de toetsing van de overige vereisten}

Als eenmaal vaststaat dat de beleggingsdienstverlener zijn civielrechtelijke zorgplicht heeft geschonden, moet de belegger het causaal verband aantonen tussen schending van de civielrechtelijke zorgplicht en de geleden schade. Vervolgens bekijkt de rechter de omvang van de schade en ook toetst hij of er wellicht sprake is van omstandigheden die de te vergoeden schade verminderen, zoals eigen schuld. De vraag rijst of het specifieke feit dat de beleggingsdienstverlener zijn civielrechtelijke zorgplicht heeft geschonden de toetsing van de overige vereisten beïnvloedt. Leidt schending van deze civielrechtelijke zorgplicht bijvoorbeeld tot een uitzondering op de toetsing van de overige vereisten? ${ }^{\mathbf{1 0}}$ Hierna bespreek ik in hoeverre schending van de civielrechtelijke zorgplicht de toetsing van de overige vereisten beïnvloedt. ${ }^{11}$ 


\subsection{Relativiteit}

De geschonden norm moet daadwerkelijk strekken tot bescherming van de benadeelde in zijn geschonden belang, oftewel de relativiteit moet vast komen te staan. ${ }^{\mathbf{1 2}}$ Bij schending van de civielrechtelijke zorgplicht is de relativiteit - voor zover het gaat om schending van een norm uit de Wft of het Bgfo ${ }^{\mathbf{1 3}}$ - in beginsel gegeven, nu het doel van de Wft en het Bgfo mede is om consumenten te beschermen tegen onbehoorlijk handelen van financiële ondernemingen. ${ }^{\mathbf{1 4}}$ Dit betekent dat de geschonden norm strekt tot bescherming van het geschonden belang van de belegger. ${ }^{\mathbf{1 5}}$ In de jurisprudentie is echter wel enige nuance aangebracht op het uitgangspunt dat de relativiteit gegeven is bij schending van een norm uit de Wft of het Bgfo. ${ }^{\mathbf{1 6}}$ Deze nuance komt er kort gezegd op neer dat de relativiteit niet alleen gegeven moet zijn ten aanzien van de belegger, maar ook ten aanzien van de schade. Wanneer de belegger per saldo een positief resultaat heeft, maar uit enkele transacties schade voortvloeit, dan is niet voldaan aan het relativiteitsvereiste, omdat de norm de belegger wel beschermt tegen grote financiële risico's, maar niet strekt tot een zo selectieve bescherming tegen elk verlies dat de belegger lijdt, aldus de Hoge Raad. ${ }^{17}$

\subsection{Causaal verband}

Vervolgens komt de rechter toe aan het causaal verband tussen schending van de civielrechtelijke zorgplicht en de schade die de belegger heeft geleden. ${ }^{\mathbf{1 8}}$ De hoofdregel bij het conditio sine qua non (csqn)-verband is dat de benadeelde de feiten waaruit de schending van de civielrechtelijke zorgplicht volgt, moet stellen en bij weerlegging door de wederpartij ook moet bewijzen. De rechter komt de benadeelde enigszins tegemoet, doordat 'slechts' vast hoeft komen te staan dat de benadeelde bijvoorbeeld een waarschuwing van de wederpartij met een redelijke mate van zekerheid zou hebben opgevolgd. ${ }^{19}$ Deze hoofdregel is bij beleggingsdienstverlening van overeenkomstige toepassing. ${ }^{20}$ Bij beleggingsdienstverlening kan het voor de benadeelde erg lastig zijn om aan voornoemd criterium te voldoen. Dit komt onder andere door de cruciale rol van het eigen handelen van de belegger bij sommige typen beleggingsdienstverlening. ${ }^{21}$ Bij beleggingsadvies en execution onlydienstverlening is het de belegger zelf die de beslissingen neemt. In het kader van het csqn-verband moet vast komen te staan dat de schade niet ontstaan zou zijn als de beleggingsdienstverlener de belegger op de juiste wijze had gewaarschuwd, omdat de belegger de waarschuwing dan zou hebben opgevolgd. ${ }^{\mathbf{2 2}}$

In algemene zin kunnen er uitzonderingen - de omkeringsregel en proportionele aansprakelijkheid ${ }^{\mathbf{2 3}}$ - op de hoofdregel van toepassing zijn als de benadeelde problemen heeft met het bewijzen van het csqn- 
verband. Dergelijke uitzonderingen zijn tot nu toe nog niet toegepast bij schending van de civielrechtelijke zorgplicht. De Hoge Raad nam daarentegen bij schending van de civielrechtelijke zorgplicht wel de ad-hocomkeringsregel aan. Dat was het geval in de effectenleasearresten. ${ }^{\mathbf{2 4}}$ De Hoge Raad oordeelt dat de aanbieder van het beleggingsproduct moet onderbouwen dat de belegger de overeenkomst ook zou zijn aangegaan als de aanbieder de zorgplicht niet zou hebben geschonden. De toepassing van deze adhocomkeringsregel leidt er dus toe dat de bewijslast om het csqnverband aan te tonen niet bij de belegger ligt, maar dat de aanbieder juist het tegenovergestelde moet bewijzen. Het gevolg is dat als de dienstverlener niet kan aantonen dat de belegger de overeenkomst ook zou zijn aangegaan als de zorgplicht niet zou zijn geschonden, het csqn-verband vaststaat. ${ }^{25}$ De rechtvaardiging voor de toepassing van deze ad-hocomkeringsregel vindt de Hoge Raad in het feit dat de waarschuwingsplicht - die in casu door de aanbieder van een beleggingsproduct geschonden is - juist strekt tot het waarschuwen van de belegger voor onnodige risico's. ${ }^{\mathbf{2 6}}$ Uit de jurisprudentie blijkt dat de toepassing van de ad-hocomkeringsregel niet beperkt is tot de effectenlease-arresten. De Hoge Raad paste de ad-hocomkeringsregel ook in een situatie van beleggingsadvies toe. ${ }^{27} \mathrm{Er}$ lijkt geen sprake te zijn van algemene toepasselijkheid van de ad-hocomkeringsregel bij schending van de civielrechtelijke zorgplicht, maar toepassing in een individueel geval is ook niet uitgesloten. ${ }^{\mathbf{2 8}}$

\subsection{Schade}

Als het causaal verband vast is komen te staan, gaat de rechter over tot de bepaling van de omvang van de schade. Het uitgangspunt is dat de beleggingsdienstverlener de belegger in de positie moet brengen alsof hij zijn civielrechtelijke zorgplicht niet geschonden heeft. ${ }^{29} \mathrm{Bij}$ schending van de civielrechtelijke zorgplicht is het bepalen van deze hypothetische situatie soms lastig en dat maakt de schadeberekening niet eenvoudig..$^{\mathbf{3 0}} \mathrm{Als}$ het causaal verband vaststaat, is weliswaar aannemelijk dat de belegger zich bijvoorbeeld door de waarschuwing zou hebben laten beïnvloeden en niet was gaan beleggen in een bepaald product, maar is niet duidelijk wat hij dan wel zou hebben gedaan. Was hij dan gaan beleggen in een ander financieel product, en zo ja, in welk product dan? Het antwoord op die vragen is van belang om de hypothetische situatie vast te stellen. ${ }^{\mathbf{3 1}}$ Tot op heden lijken deze moeilijkheden bij beleggingsdienstverlening geen uitzondering op de hoofdregel te rechtvaardigen, nu er bij schending van de civielrechtelijke zorgplicht bij de toets van de schade nog geen uitzondering is toegepast. ${ }^{\mathbf{2}}$ De belegger moet dus zelf zijn schade vaststellen en gemotiveerd onderbouwen.

\subsection{Eigen schuld}


Bij eigen schuld kan daarentegen bij schending van de civielrechtelijke zorgplicht wel sprake zijn van een afwijkende benadering ten opzichte van de algemene regels bij het leerstuk van eigen schuld. ${ }^{\mathbf{3 3}}$ In het algemeen is de vraag bij de toets van eigen schuld of de benadeelde zich anders heeft gedragen dan een redelijk ander persoon zou hebben gedaan in die omstandigheden. ${ }^{\mathbf{3 4}} \mathrm{Als}$ het antwoord op die vraag bevestigend is, dan is de schade deels veroorzaakt door een omstandigheid toe te rekenen aan de benadeelde en vermindert de eigen schuld van de benadeelde de omvang van de schade. ${ }^{35}$

Bij beleggingsdienstverlening draagt de belegger - afhankelijk van het type beleggingsdienstverlening - een bepaalde mate van verantwoordelijkheid over aan de beleggingsdienstverlener. Dat leidt tot de vraag in hoeverre de aanname van eigen schuld te rechtvaardigen is wanneer de beleggingsdienstverlener zijn civielrechtelijke zorgplicht heeft geschonden. ${ }^{\mathbf{3 6}}$ Mijns inziens is daarop geen eenduidig antwoord te geven. Als een beleggingsdienstverlener niet waarschuwt voor de risico's, maar de belegger zich daarnaast onvoldoende verdiept in de eigenschappen of risico's van een product, is eigen schuld mijns inziens te rechtvaardigen. ${ }^{\mathbf{3}}$ Als een belegger het beheer van zijn vermogen echter uitbesteedt, lijkt eigen schuld weer minder voor de hand te liggen. ${ }^{\mathbf{3 8}}$

Uit de jurisprudentie blijkt dat de bepaling van een eventuele mate van eigen schuld door de belegger wordt beïnvloed door het feit dat sprake is van schending van de civielrechtelijke zorgplicht. Die invloed komt als volgt tot uiting. Allereerst blijkt dat fouten van de belegger voortvloeiend uit zijn eigen lichtvaardigheid of gebrek aan inzicht in beginsel minder zwaar wegen dan fouten van de beleggingsdienstverlener. ${ }^{39}$ Concreet leidt dit ertoe dat het percentage eigen schuld van de belegger in principe tot $50 \%$ kan bedragen.

Alhoewel bij beleggingsdienstverlening sprake is van een grotere mate van afhankelijkheid dan in veel andere verhoudingen is eigen schuld dus niet uitgesloten. Wel lijkt de eigen schuld van de belegger beperkt te zijn tot $50 \%$, omdat fouten van de belegger in beginsel minder zwaar wegen dan fouten van de beleggingsdienstverlener. In algemene zin kan het feit dat de beleggingsdienstverlener zijn civielrechtelijke zorgplicht heeft geschonden de toetsing van de overige vereisten beïnvloeden. Of dat in een specifiek geval zo is, is afhankelijk van de omstandigheden van het geval.

\section{De civielrechtelijke zorgplicht van de beleggingsdienstverlener; MiFID (II) bepaalt}

In de vorige paragraaf besprak ik de invloed van schending van de civielrechtelijke zorgplicht door de beleggingsdienstverlener op de toetsing van de overige vereisten van onrechtmatige daad en 
wanprestatie in de huidige benadering. Mijns inziens wordt in deze benadering een te marginale rol toegekend aan de toezichtrechtelijke regels. Waarom aan de toezichtrechtelijke regels een prominentere rol binnen de civielrechtelijke zorgplicht toegekend moet worden, licht ik in deze paragraaf toe. In paragraaf 4 bespreek ik vervolgens of dat standpunt een ander licht werpt op de huidige invloed van schending van de civielrechtelijke zorgplicht op de toetsing van de overige vereisten (zoals besproken in par. 2).

In de huidige benadering van de civielrechtelijke zorgplicht is de toezichtrechtelijke wet- en regelgeving slechts een van de aspecten die een rol spelen bij de invulling daarvan. Praktisch gezien heeft dit tot gevolg dat uit de civielrechtelijke zorgplicht soms strengere normen voortvloeien voor de beleggingsdienstverlener dan uit de Europese toezichtregels..$^{40}$ In deze huidige benadering is de toezichtrechtelijke wet- en regelgeving dus niet doorslaggevend voor de bepaling van de omvang van de civielrechtelijke zorgplicht. ${ }^{41}$ Mijns inziens kan deze benadering na de invoering van $\mathrm{MiFID}^{42}$ geen stand meer houden. Dit licht ik hierna toe. Overigens is op 3 januari 2018 haar opvolger MiFID II ingevoerd. Met betrekking tot het maximumharmoniserende karakter brengt MiFID II geen wijzigingen ten opzichte van MiFID met zich. Hetgeen hierna volgt, geldt dus mijns inziens al vanaf de invoering van MiFID in 2007.

Uit het toezichtrecht, en meer specifiek uit MiFID (II), volgt dat de beleggingsdienstverlener zich op loyale, billijke en professionele wijze moet inzetten voor de belangen van zijn cliënt. ${ }^{43}$ Het blijft niet bij deze algemene verplichting. Deze verplichting wordt vervolgens ook nader uitgewerkt in deelverplichtingen. ${ }^{44}$ Deze algemene verplichting en haar deelverplichtingen tezamen noem ik de MiFIDloyaliteitsverplichting, omdat de beleggingsdienstverlener zich op loyale, billijke en professionele wijze moet inzetten voor de belangen van zijn cliënt.

Interessant is dat MiFID - en ook haar opvolger MiFID II - voorziet in maximumharmonisatie. Dit blijkt zowel uit haar doel en haar strekking als uit de bepalingen in MiFID (II) zelf.45 Zo blijkt bijvoorbeeld uit de overwegingen dat MiFID (II) een allesomvattend regelgevingskader is en aanvulling of afwijking slechts toegestaan is als dit expliciet uit MiFID (II) volgt. ${ }^{\mathbf{6}}$ Dit maximumharmoniserende karakter van MiFID (II) leidt ertoe dat de nationale wetgever zowel geen strengere als geen soepelere regels mag opstellen ten opzichte van MiFID (II). Mijns inziens strekt dit maximumharmoniserende karakter zelfs zover dat op nationaal niveau ook geen aanvullende normen uit privaatrechtelijke open normen mogen voortvloeien. ${ }^{47}$ MiFID (II) is namelijk gericht aan alle overheidsorganen en nu de rechter ook een overheidsorgaan is, is ook hij gebonden aan het maximumharmoniserende karakter van MiFID (II). Het lijkt er dus op 
dat ook de civiele rechter geen strengere of soepelere regels mag hanteren dan de regels uit MiFID (II). Concreet betekent dit standpunt dat de MiFID-loyaliteitsverplichting dwingend de omvang van de civielrechtelijke zorgplicht van de beleggingsdienstverlener bepaalt. ${ }^{48}$

In eerste instantie lijkt voorgaand standpunt onverenigbaar te zijn met de huidige benadering van de Hoge Raad, waarin de Europese toezichtregels slechts een van de aspecten zijn die een rol spelen bij de invulling van de civielrechtelijke zorgplicht. ${ }^{49}$ Een nadere blik leert echter dat de zaken die aan de Hoge Raad zijn voorgelegd over de civielrechtelijke zorgplicht speelden voordat MiFID en MiFID II in werking waren getreden. Ten tijde van die zaken was de Europese richtlijn Investment Service Directive (ISD) van toepassing en deze richtlijn voorzag in minimumharmonisatie. Destijds was het nog wel toegestaan om op nationaal niveau strengere regels te hanteren dan voortvloeiend uit de Europese richtlijn. Inmiddels is dat sinds de inwerkingtreding van MiFID veranderd, zoals ik hiervoor beargumenteerde.

Als het uitgangspunt is dat de MiFID-loyaliteitsverplichting dwingend de omvang van de civielrechtelijke zorgplicht van de beleggingsdienstverlener bepaalt dan wel dat MiFID (II) ten minste doorwerkt in ons civiele recht, rijst de vraag of dit uitgangspunt een ander licht werpt op de invloed van schending van de civielrechtelijke zorgplicht op de toetsing van de overige vereisten. Voordat ik die vraag kan beantwoorden, is allereerst van belang of er op Europees niveau is geregeld welke gevolgen moeten worden verbonden aan schending van de MiFID-loyaliteitsverplichting, die doorwerkt in de civielrechtelijke zorgplicht. Dat is niet zo. Volgens het Hof van Justitie van de Europese Unie moeten die gevolgen naar intern (nationaal) recht worden bepaald. Wel oordeelde het Hof dat bij de bepaling van de gevolgen naar nationaal recht twee beginselen in acht moeten worden genomen..$^{\mathbf{o}}$

Het eerste beginsel is het gelijkwaardigheidsbeginsel. Dit beginsel houdt in dat nationaalrechtelijke voorwaarden die van toepassing zijn op een vordering op grond van Unierecht niet ongunstiger mogen zijn dan de voorwaarden voor een soortgelijke vordering op grond van nationaal recht. ${ }^{\mathbf{1}}$ In deze paragraaf kwam al aan bod dat de MiFIDloyaliteitsverplichting mijns inziens de omvang van de civielrechtelijke zorgplicht bepaalt. Dat betekent dat de vordering op grond van het Unierecht en de vordering op grond van nationaal recht op dezelfde norm gebaseerd zijn, namelijk de MiFID-loyaliteitsverplichting. Van verschillende voorwaarden is dan dus geen sprake. Het gelijkwaardigheidsbeginsel lijkt dan ook geen ander licht te werpen op de huidige benadering van de toetsing van de overige vereisten, die ik in paragraaf 2 uiteenzette. 
Het tweede beginsel is het effectiviteitsbeginsel. Dit beginsel houdt in dat nationaalrechtelijke voorwaarden niet zodanig mogen zijn dat zij de uitoefening van in het Unierecht verleende rechten praktisch gezien uiterst moeilijk of onmogelijk maken..$^{\mathbf{5}}$ Dit beginsel kan van invloed zijn op de toetsing van de overige vereisten van onrechtmatige daad of wanprestatie, nu ik eerder vaststelde dat MiFID en ook haar opvolger MiFID II doorwerken in de civielrechtelijke zorgplicht. ${ }^{53}$ Deze invloed licht ik toe aan de hand van een voorbeeld. Stel dat de MiFIDloyaliteitsverplichting wordt geschonden. Zoals ik hiervoor uiteenzette, bepaalt de MiFID-loyaliteitsverplichting mijns inziens de omvang van de civielrechtelijke zorgplicht. Schending van de MiFIDloyaliteitsverplichting levert dus een schending van de civielrechtelijke zorgplicht op. De belegger krijgt zijn schade echter niet vergoed, omdat hij het csqn-verband tussen schending van de civielrechtelijke zorgplicht en de ontstane schade niet kan aantonen. In dat geval leidt een nationaalrechtelijke voorwaarde - namelijk dat de belegger het csqn-verband moet aantonen - ertoe dat de belegger geen geslaagd beroep kan doen op schending van de MiFID-loyaliteitsverplichting, die tot uitdrukking komt in de civielrechtelijke zorgplicht. Oftewel: het wordt de belegger uiterst moeilijk of onmogelijk gemaakt om een geslaagd beroep te doen op schending van de MiFID-

loyaliteitsverplichting. Dat kan in strijd zijn met het effectiviteitsbeginsel. Het effectiviteitsbeginsel kan nopen tot een andere benadering van de toetsing van de overige vereisten dan de huidige benadering, als de huidige benadering ertoe zou leiden dat een beroep op schending van de civielrechtelijke zorgplicht uiterst moeilijk of onmogelijk wordt gemaakt.

Het is echter niet op voorhand te zeggen hoe de concrete toepassing van het effectiviteitsbeginsel op de toetsing van de overige vereisten uitvalt. Er moet namelijk steeds een afweging worden gemaakt tussen de belangen die gemoeid zijn met een volledig effect van het Unierecht en eventuele andere belangen. ${ }^{\mathbf{5 4}}$ Denk bij andere belangen

bijvoorbeeld aan bescherming van rechten van de verdediging of de rechtszekerheid. ${ }^{55}$ Dat nationaalrechtelijke voorwaarden een geslaagd beroep op schending van de MiFID-loyaliteitsverplichting uiterst moeilijk of onmogelijk maken, betekent dus niet per se dat het effectiviteitsbeginsel geschonden is, nu er ook ruimte is voor andere belangen. Maar in algemene zin lijkt het effectiviteitsbeginsel - in tegenstelling tot het gelijkwaardigheidsbeginsel - dus wel van invloed te kunnen zijn op de toetsing van de overige vereisten bij schending van de civielrechtelijke zorgplicht. Deze overige vereisten zijn immers nationaalrechtelijke voorwaarden, die het beroep op de MiFIDloyaliteitsverplichting uiterst moeilijk of onmogelijk kunnen maken.

\section{De invloed van MiFID (II) op de toetsing van de overige vereisten bij schending van de civielrechtelijke zorgplicht}


In paragraaf $3 \mathrm{kwam}$ ik tot de conclusie dat op nationaal niveau het effectiviteitsbeginsel in acht zou moeten worden genomen bij de toets van de overige vereisten bij schending van de civielrechtelijke zorgplicht vanwege de doorwerking van MiFID (II) in ons civiele recht. In de huidige benadering van de Hoge Raad wordt met het effectiviteitsbeginsel nog geen rekening gehouden. Wat hierna aan de orde komt, is op dit moment dus nog geen vaststaand recht. In deze paragraaf zet ik uiteen in hoeverre het effectiviteitsbeginsel mijns inziens noopt tot een koerswijziging van de huidige benadering van de toetsing van de overige vereisten - die ik in paragraaf 2 uiteenzette bij schending van de civielrechtelijke zorgplicht.56

\subsection{Relativiteit}

Met betrekking tot het relativiteitsvereiste bleek uit paragraaf 2 dat dit vereiste bij schending van de civielrechtelijke zorgplicht in beginsel gegeven lijkt te zijn. Op dit uitgangspunt is in de jurisprudentie echter wel een nuance gemaakt en de relativiteit is dus niet in alle gevallen gegeven. In die uitzonderingssituatie dat de relativiteit ontbreekt bij schending van de civielrechtelijke zorgplicht, komt niet vast te staan dat de beleggingsdienstverlener zijn civielrechtelijke zorgplicht geschonden heeft en krijgt de belegger zijn schade niet vergoed. Dat kan problematisch zijn in het licht van het effectiviteitsbeginsel. Een nationaalrechtelijke voorwaarde (de relativiteit moet vast komen te staan) maakt een geslaagd beroep op schending van de MiFIDloyaliteitsverplichting - die tot uiting komt in de civielrechtelijke zorgplicht - dan uiterst moeilijk of onmogelijk. Dit betekent dat het effectiviteitsbeginsel ertoe zou moeten kunnen leiden dat de relativiteit bij schending van de civielrechtelijke zorgplicht een gegeven is. Of dat in een specifiek geval ook daadwerkelijk zo zou moeten zijn, is afhankelijk van de uitkomst van de belangenafweging, die ik in paragraaf 3 besprak.

\subsection{Causaal verband}

Uit paragraaf 2 volgt verder dat schending van de civielrechtelijke zorgplicht bij de toets van het causaal verband kan leiden tot een aanname van de ad-hocomkeringsregel, omdat het aantonen van een causaal verband bij schending van de civielrechtelijke zorgplicht problematisch kan zijn voor de belegger. De ad-hocomkeringsregel wordt echter niet standaard aangenomen bij schending van de civielrechtelijke zorgplicht. In de gevallen dat deze regel niet wordt aangenomen, zouden de problemen bij het aantonen van het csqnverband bij schending van de civielrechtelijke zorgplicht ertoe kunnen leiden dat het voor de belegger uiterst moeilijk of onmogelijk is om een beroep te doen op de MiFID-loyaliteitsverplichting (die vult immers mijns inziens de civielrechtelijke zorgplicht in ${ }^{57}$ ). Afhankelijk van de belangenafweging die ik in paragraaf 3 besprak - tussen een 
volledig effect van het Unierecht en eventuele andere belangen -, kan de toets van het causaal verband in de huidige benadering dus in strijd zijn met het effectiviteitsbeginsel.

Het voert mijns inziens echter te ver om te concluderen dat de civiele rechter in het licht van het effectiviteitsbeginsel in algemene zin bij schending van de civielrechtelijke zorgplicht een vereenvoudiging van het csqn-verband (bijvoorbeeld de ad-hocomkeringsregel) zou moeten aannemen. Het aantonen van het csqn-verband is namelijk niet bij alle deelverplichtingen van de civielrechtelijke zorgplicht problematisch. Bij schending van de waarschuwingsplicht kan het aantonen van een csqn-verband problematisch zijn omdat het voor de belegger lastig is om aan te tonen dat hij zijn beleggingsbeslissing ook daadwerkelijk door deze waarschuwing zou hebben laten beïnvloeden. ${ }^{58}$ Bij een andere deelverplichting - zoals de weigeringsplicht - ligt dat anders. Als de beleggingsdienstverlener de order immers had geweigerd, was de schade gewoonweg niet ontstaan. In dat geval is het voor de belegger niet problematisch om het csqn-verband aan te tonen. Bij een schending van de weigeringsplicht zal de belegger geen 'extra' problemen ervaren bij het aantonen van het csqn-verband in vergelijking met situaties buiten de beleggingsdienstverlening en is het voor de belegger praktisch gezien dus ook niet uiterst moeilijk of onmogelijk om een beroep te doen op de MiFIDloyaliteitsverplichting. Het effectiviteitsbeginsel komt dan ook niet in het geding. 59

Rechtvaardigt het effectiviteitsbeginsel dan wellicht de aanname van een vereenvoudiging van het csqn-verband (zoals de adhocomkeringsregel) specifiek bij waarschuwings- dan wel informatieplichten omdat beleggers vaak bij die deelverplichtingen problemen ondervinden bij het aantonen van het csqn-verband? Op grond van World Online zou men kunnen betogen dat die vraag bevestigend beantwoord moet worden. De Hoge Raad nam in World Online ook de ad-hocomkeringsregel aan. In die zaak ging het om prospectusaansprakelijkheid en die regeling vloeit - evenals de toezichtrechtelijke regels die de beleggingsdienstverlener moet naleven - voort uit een Europese richtlijn. ${ }^{60}$ Zowel het doel van de regeling over prospectusaansprakelijkheid als het doel van MiFID (II) is beleggersbescherming. In World Online ondervinden de benadeelden problemen met het aantonen van het csqn-verband en de Hoge Raad komt tot de aanname van de ad-hocomkeringsregel. De rechtvaardiging van de aanname van de ad-hocomkeringsregel vloeit in die zaak volgens de Hoge Raad voort uit het effectiviteitsbeginsel. ${ }^{61}$ Omdat ook de waarschuwings- dan wel informatieplichten in het kader van de civielrechtelijke zorgplicht van de beleggingsdienstverlener een Europeesrechtelijke oorsprong hebben, kan men in lijn met World Online betogen dat het effectiviteitsbeginsel bij waarschuwings- dan wel informatieplichten 
leidt tot de aanname van de ad-hocomkeringsregel. ${ }^{62}$

Ik heb echter mijn twijfels bij de analoge toepassing van de redenering van de Hoge Raad uit World Online bij schending van de civielrechtelijke zorgplicht. De Hoge Raad gaat er in World Online van uit dat de gemiddelde consument is beïnvloed in zijn handelen door de foutieve informatie in het prospectus. ${ }^{63}$ Bij beleggingsdienstverlening is het echter nog maar de vraag of een belegger de waarschuwing ter harte zou hebben genomen als deze wel afgegeven zou zijn, en of hij dus beïnvloed zou zijn door een eventueel foutief advies. Daar komt nog bij dat het effectiviteitsbeginsel een belangenafweging inhoudt en daaraan zou men voorbijgaan als bij schending van waarschuwingsdan we informatieplichten in algemene zin een ad-hocomkeringsregel wordt aangenomen. ${ }^{64}$ Ook de algemene toepassing van de adhocomkeringsregel enkel bij schending van de informatie- dan wel waarschuwingsplicht voert mijns inziens dus te ver. Los gezien daarvan kán het effectiviteitsbeginsel er in een specifiek geval mijns inziens wel toe leiden dat de ad-hocomkeringsregel toepassing zou moeten verdienen. Maar de civiele rechter zou dit geval voor geval moeten bekijken. ${ }^{65}$

\subsection{Schade}

Na de vaststelling van het causaal verband komt de rechter toe aan de berekening van de schade. Het effectiviteitsbeginsel lijkt bij de berekening van de schade geen koerswijziging te impliceren met betrekking tot de huidige benadering - die ik in paragraaf 2 uiteenzette - waarin het effectiviteitsbeginsel niet (expliciet) wordt meegenomen. De wijze waarop de omvang van de schade bepaald moet worden, leidt er namelijk niet toe dat een beroep op de MiFIDloyaliteitsverplichting (die mijns inziens de invulling van de civielrechtelijke zorgplicht bepaalt) uiterst moeilijk of onmogelijk wordt gemaakt. Het vaststellen van de schade ziet enkel op de bepaling van de omvang van de schadevergoeding en leidt er in principe niet toe dat de belegger zijn schade niet vergoed krijgt, tenzij hij daadwerkelijk geen schade heeft geleden. ${ }^{\mathbf{6 6}}$

\subsection{Eigen schuld}

De toepassing van het effectiviteitsbeginsel op de toets van eigen schuld lijkt ook geen koerswijziging van de huidige benadering, die ik in paragraaf 2 besprak, te vereisen. De toepassing van eigen schuld leidt er immers in principe niet toe dat de belegger geen schadevergoeding meer krijgt, maar houdt een eventuele vermindering in van de te ontvangen schadevergoeding. Daarmee wordt de belegger een beroep op de MiFID-loyaliteitsverplichting (en dus mijns inziens de civielrechtelijke zorgplicht) niet uiterst moeilijk of onmogelijk gemaakt. Met uitzondering van de situatie dat de eigen 
schuld op 100\% wordt vastgesteld, leidt de toets van eigen schuld er niet toe dat de belegger geen schade meer vergoed zou krijgen. Daar komt bij dat volgens het huidige richtsnoer de eigen schuld van beleggers tot $50 \%$ kan bedragen. ${ }^{67}$ De belegger krijgt dus ten minste $50 \%$ van zijn geleden schade vergoed, waardoor mijns inziens de toets van eigen schuld een beroep op de MiFID-loyaliteitsverplichting niet uiterst moeilijk of onmogelijk maakt.

Ik concludeer dat het effectiviteitsbeginsel met betrekking tot de toets van de overige vereisten bij enkele vereisten mijns inziens tot een koerswijziging van de huidige benadering zou moeten nopen. Dat kan zijn als de civielrechtelijke zorgplicht geschonden is, maar de relativiteit niet is gegeven, of als de belegger ernstige moeilijkheden ondervindt bij het aantonen van een csqn-verband. Het voert echter te ver om aan te nemen dat het effectiviteitsbeginsel er in die gevallen toe leidt dat de relativiteit gegeven is, of dat er een vereenvoudiging van het csqn-verband zou moeten worden toegepast. Uiteindelijk komt het steeds aan op de belangenafweging in een specifiek geval.

\section{Conclusie}

In het begin van dit artikel wierp ik de vraag op of als eenmaal vaststaat dat de beleggingsdienstverlener zijn civielrechtelijke zorgplicht heeft geschonden, dit de toets van de overige vereisten van onrechtmatige daad en wanprestatie beïnvloedt. ${ }^{\mathbf{6 8}}$ Uit de jurisprudentie blijkt dat in sommige situaties zo te zijn. In die jurisprudentie hebben de toezichtrechtelijke regels vaak slechts een marginale rol bij de invulling van de civielrechtelijke zorgplicht. Mijns inziens zouden deze toezichtrechtelijke regels sinds de invoering van MiFID een prominentere positie moeten krijgen bij de bepaling van de omvang van de civielrechtelijke zorgplicht. Deze prominentere positie die aan MiFID (II) zou moeten toekomen, brengt met zich dat wij op nationaal niveau het effectiviteitsbeginsel in acht moeten nemen. Dat betekent dat een belegger een beroep op schending van de MiFIDloyaliteitsverplichting (die de civielrechtelijke zorgplicht mijns inziens invult) niet uiterst moeilijk of onmogelijk mag worden gemaakt. Voor de toets van de overige vereisten van onrechtmatige daad en wanprestatie bij schending van de civielrechtelijke zorgplicht lijkt dit in sommige gevallen een andere benadering te vereisen dan de huidige benadering.

\section{Noten}

* De tekst van dit artikel is gebaseerd op Janssens in juni 2017 verschenen dissertatie: I.P.M.J. Janssen, De civielrechtelijke zorgplicht van de beleggingsdienstverlener jegens de niet-particuliere cliënt (Onderneming en Recht, deel 101), Deventer: Wolters Kluwer 2017. 
1 Deze derden heb ik in mijn onderzoek buiten beschouwing gelaten. De Hoge Raad nam de bijzondere zorgplicht bijv. aan in HR 23 december 2005, ECLI:NL:HR:2005:AU3713, JOR 2006/20, NJ 2006/289 m.nt. M.R. Mok (Safe Haven).

2 Inmiddels lijkt duidelijk dat de beleggingsdienstverlener ook bij niet-particuliere beleggers een civielrechtelijke zorgplicht in acht moet nemen. Hof 's-Hertogenbosch 15 april 2014, ECLI:NL:GHSHE:2014:1052, JOR 2014/168 m.nt. B.T.M. van der Wiel \& I.J.F. Wijnberg, Ondernemingsrecht 2014/92 m.nt. T.M.C. Arons (Westkant/ABN AMRO); Janssen 2017, p. 138-141. De vraag is dan niet zozeer of de bijzondere zorgplicht aanvaard jegens particuliere cliënten ook van toepassing is bij niet-particuliere cliënten, maar welke zorg de bank gezien de omstandigheden van het geval in acht moest nemen tegenover de niet-particuliere cliënt, aldus concl. A-G M.H. Wissink, ECLI:NL:PHR:2017:1057, bij HR 1 december 2017 , onder 3.8 .

3 O.a. HR 23 mei 1997, ECLI:NL:HR:1997:AG7238, NJ 1998/192 m.nt. C.J. van Zeben (Rabo/Everaars), r.o. 4.3; HR 11 juli 2003, ECLI:NL:HR:2003:AF7419, JOR 2003/199 m.nt. K. Frielink, NJ 2005/103 m.nt. C.E. du Perron, AA 2003, afl. 12, p. 929-937 m.nt. T. Hartlief (Van Zuylen/Rabo Schaijk-Reek); HR 5 juni 2009, ECLI:NL:HR:2009:BH2815, JOR 2009/199 m.nt. C.W.M. Lieverse, NJ 2012/182 m.nt. J.B.M. Vranken (De Treek/Dexia); HR 5 juni 2009, ECLI:NL:HR:2009:BH2811, NJ 2012/183 m.nt. J.B.M. Vranken (Levob/Bolle); HR 5 juni 2009, ECLI:NL:HR:2009:BH2822, JOR 2009/200 m.nt. C.W.M. Lieverse, NJ 2012/184 m.nt. J.B.M. Vranken (Stichting Gedupeerden Spaarconstructie/Aegon); HR 3 februari 2012, ECLI:NL:HR:2012:BU4914, JOR 2012/116 m.nt. S.B. van Baalen, NJ 2012/95, AA 2012, afl. 10, p. 752-759 m.nt. D. Busch (Rabobank Vaart \& Vecht/X).

4 Zie Janssen 2017, p. 138-141 voor een toelichting van de keuze voor het begrip 'civielrechtelijke zorgplicht'.

5 Richtlijn 2014/65/EU; Gedelegeerde Richtlijn 2017/593/EU.

6 Het Bgfo is een nadere uitwerking van bepaalde normen uit de Wft. Dat de toezichtregels van invloed zijn op de civielrechtelijke zorgplicht blijkt o.a. uit HR 5 juni 2009, ECLI:NL:HR:2009:BH2815, JOR 2009/199 m.nt. C.W.M. Lieverse, NJ 2012/182 m.nt. J.B.M. Vranken (De Treek/Dexia); HR 5 juni 2009, ECLI:NL:HR:2009:BH2811, NJ 2012/183 m.nt. J.B.M. Vranken (Levob/Bolle); HR 5 juni 2009, ECLI:NL:HR:2009:BH2822, JOR 2009/200 m.nt. C.W.M. Lieverse, NJ 2012/184 m.nt. J.B.M. Vranken (Stichting Gedupeerden Spaarconstructie/Aegon). 
7 Bij wanprestatie kan de civielrechtelijke zorgplicht volgen uit de overeenkomst van opdracht, de redelijkheid en billijkheid en de Algemene Bankvoorwaarden. Zie voor een toelichting Janssen 2017, p. 162-166.

8 Overigens is bij onrechtmatige daad een toets van de relativiteit in de norm ingebakken.

9 Waar ik in het vervolg van dit artikel spreek van de civielrechtelijke zorgplicht doel ik specifiek op de civielrechtelijke zorgplicht van de beleggingsdienstverlener.

10 Deze strekking zette ik in par. 1 uiteen.

11 Ik beperk mij in deze paragraaf tot de bespreking van eventuele afwijkingen bij schending van de civielrechtelijke zorgplicht van de 'standaard' bij de toetsing van de overige vereisten. Voor een uitgebreide uitwerking van de 'standaardregels' bij de toetsing van deze overige vereisten verwijs ik naar Janssen 2017, p. 236-281.

12 Art. 6:163 BW.

13 In het Bgfo is o.a. de uitwerking van een aantal normen uit de $\mathrm{Wft}$ opgenomen.

14 Kamerstukken II 2005/o6, 29708, 19.

15 Art. 6:163 BW.

16 HR 4 december 2009, ECLI:NL:HR:2009:BJ7320, JOR 2010/19 m.nt. K. Frielink, NJ 2010/67 m.nt. M.R. Mok (Nabbe/Staalbankiers), r.o. 3.5 .

17 HR 4 december 2009, ECLI:NL:HR:2009:BJ7320, JOR 2010/19 m.nt. K. Frielink, NJ 2010/67 m.nt. M.R. Mok (Nabbe/Staalbankiers), r.o. 3.5. Deze zaak is pre-MiFID. Op dat moment hadden de Europeesrechtelijke toezichtregels nog geen maximumharmoniserend karakter.

18 De toets van het causaal verband is een tweeledige toets. Allereerst moet het csqn-verband vast komen te staan. Vervolgens moet de schade toe te rekenen zijn aan de schadeveroorzakende gebeurtenis (art. 6:98 BW).

19 Zie voor een bespreking van het criterium van een redelijke mate van zekerheid specifiek toegepast op beleggingsdienstverlening Janssen 2017, p. 239-240. 
20 HR 3 februari 2012, ECLI:NL:HR:2012:BU4914, JOR 2012/116 m.nt. S.B. van Baalen, NJ 2012/95, AA 2012, afl. 10, p. 752-759 m.nt. D. Busch (Rabobank Vaart \& Vecht/X), r.o. 3.7.1.

21 Zie voor uitgebreidere argumentatie Janssen 2017, p. 237-238.

22 V.M. Neering, Aansprakelijkheid bij execution only, advies en vermogensbeheer, in: D. Busch, C.J.M. Klaassen \& T.M.C. Arons, Aansprakelijkheid in de financiële sector, Deventer: Kluwer 2013, p. 373-422, p. 412.

23 HR 29 november 2002, ECLI:NL:HR:2002:AE7345, NJ 2004/304 m.nt. W.D.H. Asser, AA 2003, afl. 4, p. 307-313 m.nt. G.R. Rutgers (TFS/NS), r.o. 3.5.3 en HR 29 november 2002, ECLI:NL:HR:2002:AE7351, NJ 2004/305 m.nt. W.D.H. Asser, AA 2003, afl. 4, p. 298-306 m.nt. T. Hartlief (Kastelijn/Achtkarspelen), r.o. 3.6; C.J.M. Klaassen, Bewijs van causaal verband tussen beweerdelijk geleden beleggingsschade en schending van een informatie- of waarschuwingsplicht, in: D. Busch, C.J.M. Klaassen \& T.M.C. Arons, Aansprakelijkheid in de financiële sector, Kluwer: Deventer 2013, p. 127-174, p. 137; HR 31 maart 2006, ECLI:NL:HR:2006:AU6092, AA 2006, afl. 10, p. 736-741 (Nefalit/Karamus), r.o. 3.13.

24 Deze term is geïntroduceerd door Busch. D. Busch, annotatie bij HR 3 februari 2012, ECLI:NL:HR:2012:BU4914, AA 2012, afl. 10, p. 752-759 (Rabobank Vaart \& Vecht/X), onder 37. HR 5 juni 2009, ECLI:NL:HR:2009:BH2815, JOR 2009/199 m.nt. C.W.M. Lieverse, NJ 2012/182 m.nt. J.B.M. Vranken (De Treek/Dexia), r.o. 5.5.3; HR 5 juni 2009, ECLI:NL:HR:2009:BH2811, NJ 2012/183 m.nt. J.B.M. Vranken (Levob/Bolle), r.o. 4.7.10. Strikt genomen is er bij de effectenlease-arresten geen sprake van beleggingsdienstverlening, maar biedt de aanbieder 'slechts' effecten aan. Janssen 2017, p. 175176. Toch verdient de ad-hocomkeringsregel die in deze effectenleasearresten werd aangenomen hier bespreking, omdat op de aanbieder net zoals op de beleggingsdienstverlener een civielrechtelijke zorgplicht rust jegens zijn cliënten.

25 Janssen 2017, p. 244.

26 HR 5 juni 2009, ECLI:NL:HR:2009:BH2815, JOR 2009/199 m.nt. C.W.M. Lieverse, NJ 2012/182 m.nt. J.B.M. Vranken (De Treek/Dexia), r.o. 5.5.3; HR 5 juni 2009, ECLI:NL:HR:2009:BH2811, NJ 2012/183 m.nt. J.B.M. Vranken (Levob/Bolle), r.o. 4.7.10.

27 HR 8 februari 2013, ECLI:NL:HR:2013:BX7846, JOR 2013/108 m.nt. B.T.M. van der Wiel, NJ 2014/497 m.nt. Jac. Hijma, Ondernemingsrecht 2013/39 m.nt. J. Cornegoor (Van Lanschot 
Bankiers/MAIG c.s.).

28 Janssen 2017, p. 249.

29 Asser/Hartkamp \& Sieburgh 6-II 2013/31.

30 Janssen 2017, p. 256.

31 Zie voor een uitgebreidere omschrijving van de problemen bij het vaststellen van de hypothetische situatie bij beleggingsdienstverlening Janssen 2017, p. 255-258.

32 Een uitzondering die bij de bepaling van de omvang van de schade wel eens is toegepast, is kansschade.

33 Zie voor een uitwerking van twee andere mogelijkheden om de te vergoeden schade te verminderen - namelijk voordeelsverrekening en de schadebeperkingsplicht - Janssen 2017, p. 265-270 en 280-281.

34 Asser/Hartkamp \& Sieburgh 6-II 2013/107.

35 Art. 6:101 BW.

36 Janssen 2017, p. 272.

37 Janssen 2017, p. 273.

38 Janssen 2017, p. 272. Zie voor een voorbeeld van de aanname van eigen schuld bij vermogensbeheer Klachtencommissie DSI 30 januari 2003, 03-19. De belegger gaf de vermogensbeheerder instructies die afweken van het beleggingsbeleid en de vermogensbeheerder accepteerde deze. Zie over eigen schuld bij vermogensbeheer D. Busch, Vermogensbeheer (Monografieën BW, deel B8), Deventer: Kluwer 2014, p. 162.

39 Voor het eerst aangenomen in HR 23 mei 1997,

ECLI:NL:HR:1997:AG7238, NJ 1998/192 m.nt. C.J. van Zeben (Rabo/Everaars), r.o. 3.3.

4o Zie voor een vergelijking van de huidige benadering en de Europese toezichtregels Janssen 2017, p. 343-382.

41 Alle jurisprudentie van de Hoge Raad is pre-MiFID.

42 Richtlijn 2004/39/EG; Richtlijn 2006/73/EG.

43 Art. 24 lid 1 MiFID II (art. 19 lid 1 MiFID). 
44 Art. 24, 25, 27 en 28 MiFID II (art. 19, 21 en 22 MiFID).

45 Janssen 2017, p. 19-23.

46 Overweging 14 MiFID II (overweging 5 MiFID), overweging 7 uitvoeringsrichtlijn MiFID en art. 24 lid 12 MiFID II (art. 4 uitvoeringsrichtlijn MiFID).

47 Janssen 2017, p. 289-290. Anders: O.O. Cherednychenko, De bijzondere zorgplicht van de bank in het spanningsveld tussen het publiek- en privaatrecht, NTBR 2010/11, afl. 3, p. 66-77, p. 74.

48 Voor zover dit uitgangspunt te ver strekt, zijn er desalniettemin argumenten om alsnog vrijwillig voor dit uitgangspunt te kiezen. Janssen 2017, p. 299-312.

49 HR 5 juni 2009, ECLI:NL:HR:2009:BH2815, JOR 2009/199 m.nt. C.W.M. Lieverse, NJ 2012/182 m.nt. J.B.M. Vranken (De Treek/Dexia); HR 5 juni 2009, ECLI:NL:HR:2009:BH2811, NJ 2012/183 m.nt. J.B.M. Vranken (Levob/Bolle); HR 5 juni 2009, ECLI:NL:HR:2009:BH2822, JOR 2009/200 m.nt. C.W.M. Lieverse, NJ 2012/184 m.nt. J.B.M. Vranken (Stichting Gedupeerden Spaarconstructie/Aegon).

5o HvJ EU 30 mei 2013, C-604/11, ECLI:EU:C:2013:344 (Genil).

51 HvJ EU 19 juli 2012, C-591/10, ECLI:EU:C:2012:478 (Littlewoods Retail e.a.).

52 HvJ EU 19 juli 2012, C-591/10, ECLI:EU:C:2012:478 (Littlewoods Retail e.a.).

53 Te weten relativiteit, het causaal verband, de berekening van de schade en de mogelijkheden tot vermindering van de te vergoeden schade.

54 R. Meijer, The Rewe/Comet 'doctrine' and its implications for Dutch law, in: A.S. Hartkamp e.a. (red.), The influence of EU law on national private law, Deventer: Kluwer 2014, p. 39-56, p. 45.

55 HvJ EG 14 december 1995, C-312/93, ECLI:EU:C:1995:437, Jur. 1995, p. I-4599 (Peterbroeck, Van Campenhout \& Cie SCS/België), r.o. 14.

56 Zie over de invloed van MiFID (II) op de toets van deze overige vereisten ook D. Busch, MiFID II/MiFIR: nieuwe regels voor beleggingsondernemingen en financiële markten (preadvies voor de Vereniging voor Financieel Recht 2015), Deventer: Wolters Kluwer 
2015, p. 221-235.

57 Janssen 2017, p. 386.

58 Janssen 2017, p. 387.

59 Janssen 2017, p. 387.

60 Richtlijn 2003/71/EG (Prospectusrichtlijn). De regels die de beleggingsdienstverlener moet naleven, vloeien voort uit MiFID (II). In par. 3 ging ik uitgebreider in op de invloed van MiFID (II) op de civielrechtelijke zorgplicht.

61 HR 27 november 2009, ECLI:NL:HR:2009:BH2162, JOR 2010/43 m.nt. K Frielink, NJ 2014/201 m.nt. C.E. du Perron, AA 2010, afl. 5, p. 336-343 m.nt. M.J.G.C. Raaijmakers (World Online).

62 Busch 2015, p. 225.

63 Klaassen 2013, p. 148-149.

64 Janssen 2017, p. 388.

65 Janssen 2017, p. 389.

66 Janssen 2017, p. 389.

67 Janssen 2017, p. 389.

68 In hoeverre het onderscheid tussen de particuliere en nietparticuliere belegger hierop van invloed is, heb ik in dit artikel buiten beschouwing gelaten. In mijn proefschrift ga ik wel op dit onderscheid in Janssen 2017, p. 236-282 en 383-391.

(C) Boom juridisch 